\title{
Groundwater Quality in the Cambrian-Ordovician Aquifer System, Midwestern United States
}

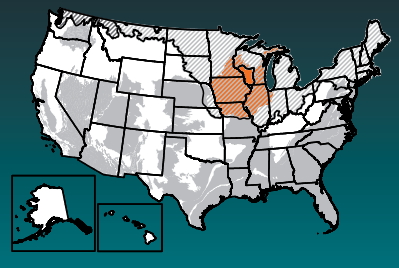

Groundwater provides nearly 50 percent of the Nation's drinking water. To help protect this vital resource, the U.S. Geological Survey (USGS) National Water-Quality Assessment (NAWQA) Project assesses groundwater quality in aquifers that are important sources of drinking water (Burow and Belitz, 2014). The Cambrian-Ordovician aquifer system constitutes one of the important areas being evaluated.

\section{Background}

The Cambrian-Ordovician (C-O) aquifer system underlies an area with a population of about 26 million people in parts of seven states that include the metropolitan areas of Chicago, Illinois; Milwaukee, Wisconsin; and Minneapolis-St. Paul, Minnesota. The C-O aquifer system ranks 9th in the Nation as a source of groundwater for public supply and 11th for domestic supply, and about 631 million gallons per day are pumped for those uses (Arnold and others, 2017a). Land use overlying the aquifer system is mostly agricultural (about 73 percent), undeveloped (about 16 percent), and urban land (about 3 percent).

Rocks of the $\mathrm{C}-\mathrm{O}$ aquifer system are mainly marine sandstones and carbonates that are present at the land surface or beneath glacial deposits in southeastern Minnesota, northeastern Iowa, Wisconsin, northern Illinois, and extreme northwestern Indiana (Young, 1992; Wilson, 2012). The rock layers dip and thicken to the south and east into structural basins in southwestern Iowa, central Illinois, and western Michigan. In eastern Wisconsin; most of Iowa, Illinois, and Indiana; and Missouri, rocks of the C-O aquifer system are buried by younger rocks. Where the aquifer is at or near land surface, modern recharge to the aquifer system occurs primarily through direct infiltration of precipitation or percolation through overlying glacial deposits. Groundwater in large parts of the buried system was likely recharged during the Pleistocene by glacial meltwater (Siegel and Mandle, 1984). Shallow groundwater flows along short flow paths to local streams, whereas deeper groundwater flows along longer flow paths towards major river valleys, Lake Michigan, or downdip structural basins (Wilson, 2012). Groundwater in large parts of the buried system, in far western Iowa, most of Missouri, south-central Illinois, and Indiana, is too saline for drinking-water use.

Groundwater quality in the $\mathrm{C}-\mathrm{O}$ aquifer system was evaluated by sampling 60 spatially distributed publicsupply wells. Public-supply wells in the C-O aquifer system typically consist of solid casing extending downward from the land surface with an open interval beneath. The length of the solid casing for wells sampled for this study ranged from about 40 to 2,250 feet, and the total well depths ranged from about 100 to 2,630 feet. Water-quality data from these wells were used to estimate the percentage of the study area with concentrations that are high, moderate, and low with respect to constituent benchmarks. The accuracy of the estimates depends upon the distribution and number of wells, not on the size of the area (Belitz and others, 2010). Samples were analyzed for a large number of water-quality constituents derived from natural and human sources.

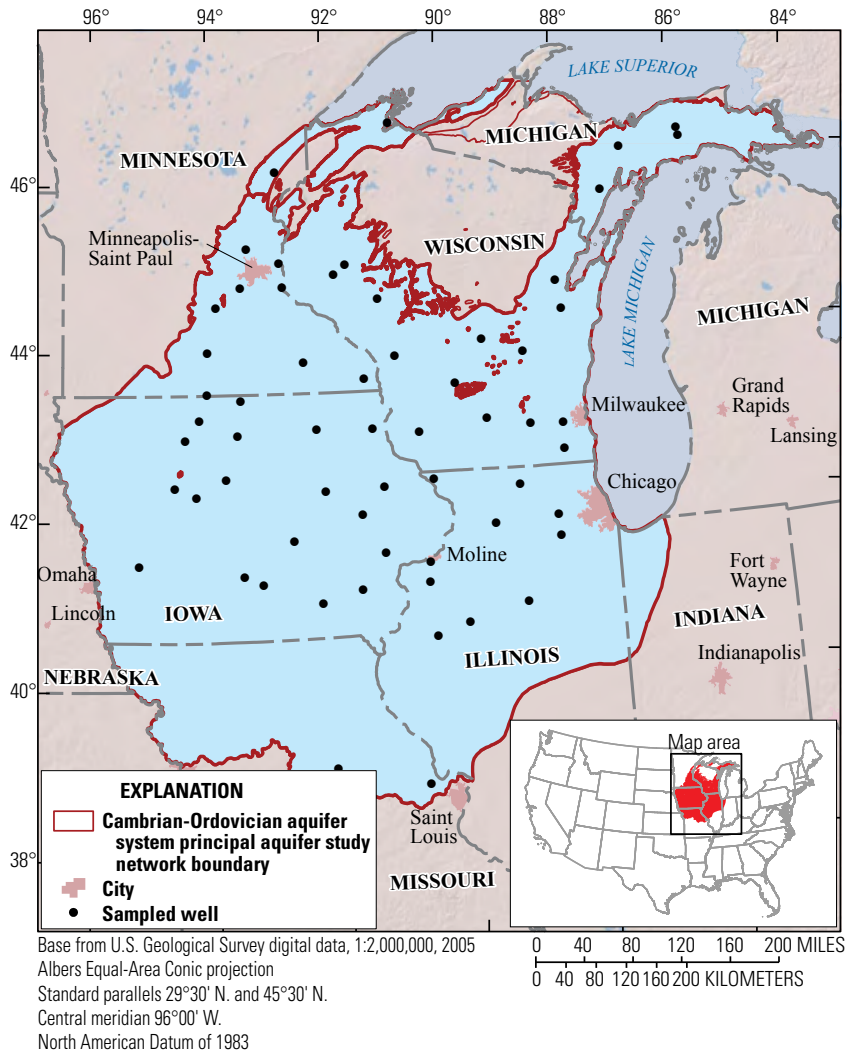

\section{Overview of Water Quality}
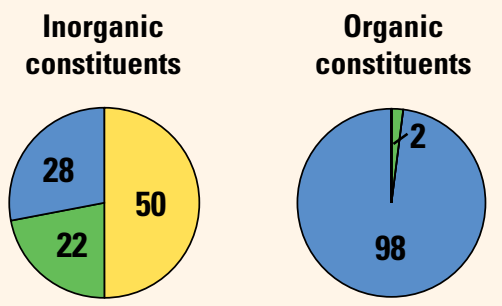

CONSTITUENT CONCENTRATIONS

$\bigcirc$ High $\bigcirc$ Moderate $\bigcirc$ Low or not detected

Values are a percentage of the study area with concentrations in the three specified categories. Percentages might not sum to 100 because of rounding.

Principal Aquifer Studies are designed to evaluate groundwater used for public supply prior to any treatment. Groundwater quality is assessed by comparing concentrations to benchmarks established for drinking-water quality. Benchmarks and definitions of high, moderate, and low concentrations are discussed in the inset box on page 3 . Water from 50 percent of the wells sampled did not have high concentrations of any constituent with a human-health benchmark.

Many inorganic constituents are naturally present in groundwater. The concentrations of inorganic constituents can be affected by natural processes as well as by human activities. One or more inorganic constituents were detected at high concentrations in about 50 percent of the study area and at moderate concentrations in about 22 percent.

Organic constituents derived from human activities are used in household, business, industrial, and agricultural products. They can enter the environment through normal usage, spills, or improper disposal. Organic constituents were not detected at high concentrations in the study area but were detected at moderate concentrations in about 2 percent of the study area. 


\section{Results: Groundwater Quality at the Depth Zone Used for Public Supply in the Cambrian-Ordovician Aquifer System}

\section{INORGANIC CONSTITUENTS}
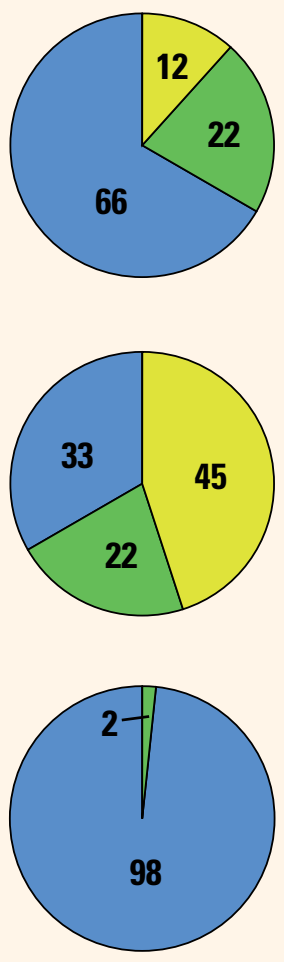

\section{Radioactive constituents}

\section{Nutrients}

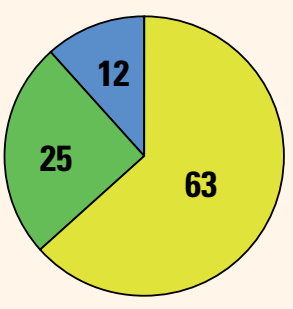

\section{Inorganic Constituents With Human-Health Benchmarks}

Trace elements and major and minor ions are naturally present in the minerals of rocks, soils and sediments, and in the water that comes into contact with those materials. Samples were analyzed for 34 trace elements and major and minor ions, of which 19 have humanhealth benchmarks. Constituents from this group were detected at high concentrations in about 12 percent of the study area (the depth zone used for public supply) and at moderate concentrations in about 22 percent. Strontium, arsenic, and fluoride were the only constituents in this group that were detected at high concentrations.

Radioactivity is the release of energy or energetic particles during spontaneous decay of unstable atoms. Humans are continuously exposed to small amounts of natural radioactivity. Most of the radioactivity in groundwater comes from the decay of isotopes of uranium and thorium that are naturally present in minerals in aquifer materials. Samples were analyzed for eight radioactive constituents, of which four have human-health benchmarks. One of the four benchmarks is for the combined concentration of radium-226 plus radium-228 isotopes (combined radium). Radioactive constituents were present at high levels in about 45 percent of the study area and at moderate levels in about 22 percent. Combined radium concentrations and gross-alpha and gross-beta activity were present at high concentrations.

Nutrients are naturally present at low concentrations in groundwater; high and moderate concentrations (relative to human-health benchmarks) generally result from human activities. Samples were analyzed for five nutrients, of which two have human-health benchmarks. Common sources of nutrients, aside from soils, include fertilizer applied to crops and landscaping, seepage from septic systems, and human and animal waste. No nutrients were detected at high concentrations in the study area. Nitrate was detected at moderate concentrations in about 2 percent of the study area.

\section{Inorganic Constituents and Field Measurements With Non-Health Benchmarks}

(Not included in water-quality overview charts shown on the front page)

Some constituents affect the aesthetic properties of water, such as taste, color, and odor, or can create nuisance problems, such as staining and scaling. The benchmarks used for these constituents were non-regulatory secondary maximum contaminant level (SMCL) benchmarks established for public drinking water. Some constituents, such as fluoride and manganese, have human-health benchmarks and SMCLs. Samples were analyzed for 11 constituents that have SMCLs. One or more of these were present at high concentrations or values relative to the SMCL in about 63 percent of the study area and at moderate concentrations in about 25 percent.

Total dissolved solids (TDS) concentration is a measure of the salinity of the groundwater, based primarily on the concentrations of ions, and all water naturally contains TDS as a result of the weathering and dissolution of minerals in rocks and sediments. Concentrations of TDS can be high because of natural factors or as a result of human activities, such as applications to the land surface of road salt, fertilizers, or other chemicals in urban or agricultural areas. Most of the study area had high (40 percent) or moderate (37 percent) concentrations of TDS. Sulfate and chloride were present at high concentrations in about 23 and 8 percent of the study area, respectively, and at moderate concentrations in 17 and 2 percent, respectively. Fluoride was present at high concentrations relative to the SMCL in about 15 percent of the study area and at moderate concentrations in 22 percent.

Anoxic conditions in groundwater (low amounts of dissolved oxygen) can result in the release of iron and manganese in minerals to the groundwater. Iron was present at high concentrations relative to the SMCL in about 40 percent of the study area and at moderate concentrations in about 17 percent. Manganese was present at high concentrations relative to the SMCL in about 12 percent of the study area and at moderate concentrations in about 16 percent.

In some areas, the $\mathrm{pH}$ of the groundwater was not in the SMCL range of 6.5 to 8.5. The $\mathrm{pH}$ did not meet the standard in about 2 percent of the study area because it was less than 6.5 , which is acidic and potentially corrosive. 


\section{Results: Groundwater Quality at the Depth Zone Used for Public Supply in the Cambrian-Ordovician Aquifer System}

\section{ORGANIC CONSTITUENTS}

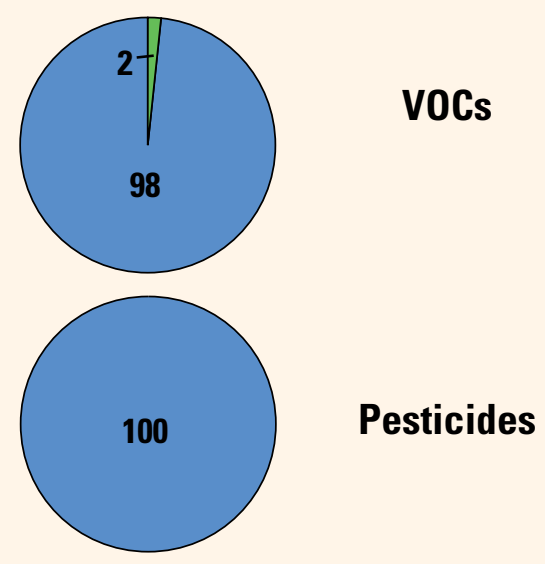

\section{Volatile Organic Compounds With Human-Health Benchmarks}

Volatile organic compounds (VOCs) are present in many household, commercial, industrial, and agricultural products and are characterized by their tendency to volatilize (evaporate). Samples were analyzed for 90 VOCs, of which 38 have human-health benchmarks. VOCs were not detected at high concentrations in the study area but were detected at moderate concentrations in about 2 percent.

\section{Pesticides With Human-Health Benchmarks}

Pesticides, including herbicides, insecticides, and fumigants, are applied to crops, gardens and lawns, around buildings, and along roads to help control unwanted vegetation (weeds), insects, fungi, and other pests. Samples were analyzed for 227 pesticide compounds (pesticides and their breakdown products), of which 119 have human-health benchmarks. Pesticides were not detected at high or moderate concentrations in the study area.

\section{BENCHMARKS FOR EVALUATING GROUNDWATER QUALITY}

The USGS NAWQA Project uses benchmarks established for drinking water to provide context for evaluating the quality of untreated groundwater. The quality of water received by consumers can be different, because after withdrawal, groundwater may be treated prior to delivery. Federal regulatory benchmarks for protecting human health are used for this evaluation of water quality when available. Otherwise, non-regulatory human-health benchmarks and non-regulatory aesthetic benchmarks are used. Not all constituents analyzed have benchmarks and, thus, are not considered in this context. Out of 55 inorganic constituents and properties and 317 organic constituents, 24 and 157, respectively, have human-health benchmarks.

\section{PERCENTAGE OF STUDY AREA}

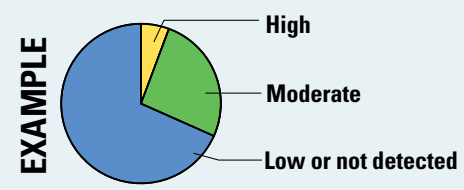

Values are a percentage of the study area with concentrations in the three specified categories. Percentages might not sum to 100 because of rounding.

Concentrations are considered high if they are greater than a human-health benchmark (Toccalino and others, 2014) or SMCL. For inorganic constituents, concentrations are moderate if they are greater than one-half of a benchmark. For organic constituents, concentrations are moderate if they are greater than one-tenth of a benchmark; this lower threshold is used because organic constituents are generally less prevalent and have lower concentrations relative to benchmarks than inorganic constituents (Toccalino and others, 2004).

\section{Benchmark Type and Value for Selected Constituents}

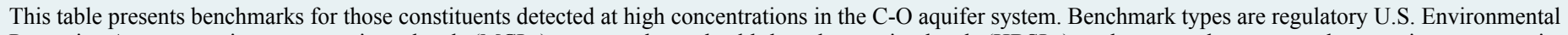

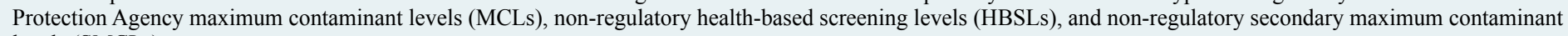
levels (SMCLs).

[Abbreviations: ppb, part per billion or microgram per liter $(\mu \mathrm{g} / \mathrm{L})$; ppm, part per million or milligram per liter $(\mathrm{mg} / \mathrm{L}) ; \mathrm{pCi} / \mathrm{L}, p$ icocurie per liter; $\mathrm{mrem} \mathrm{yr}^{-1}$, millirem per year]

\begin{tabular}{|c|c|c|c|c|c|}
\hline \multirow{2}{*}{ Constituent } & \multicolumn{2}{|c|}{ Benchmark } & \multirow{2}{*}{ Constituent } & \multicolumn{2}{|c|}{ Benchmark } \\
\hline & Type & Value & & Type & Value \\
\hline Fluoride & MCL & $4 \mathrm{ppm}$ & Fluoride & SMCL & $2 \mathrm{ppm}$ \\
\hline Arsenic & MCL & $10 \mathrm{ppb}$ & Chloride & SMCL & $250 \mathrm{ppm}$ \\
\hline Strontium & MCL & $4,000 \mathrm{ppb}$ & Sulfate & SMCL & $250 \mathrm{ppm}$ \\
\hline Ra-226+Ra-228 & MCL & $5 \mathrm{pCi} / \mathrm{L}$ & Total dissolved solids (TDS) & SMCL & $500 \mathrm{ppm}$ \\
\hline Gross-alpha activity & MCL & $15 \mathrm{pCi} / \mathrm{L}$ & Iron & SMCL & $300 \mathrm{ppb}$ \\
\hline Gross-beta activity & $\begin{array}{c}\text { Screening } \\
\text { level }\end{array}$ & 4 mrem $y^{-1}$ & Manganese & SMCL & $50 \mathrm{ppb}$ \\
\hline
\end{tabular}




\section{High Concentrations of Combined Radium Were}

\section{Common}

The U.S. Environmental Protection Agency MCL for radium is based on the summed concentration of radium-226 and radium-228 (combined radium) and is set at 5 picocuries per liter $(\mathrm{pCi} / \mathrm{L})$. Combined radium concentrations were present at high concentrations in about 42 percent of the study area; however, the proportion varied depending on whether the aquifer is buried by younger rocks or not. Combined radium concentrations were moderate or high in about 37 percent of the area not buried by younger rocks, whereas they were moderate or high in about 91 percent of the area that is buried by younger rocks. The difference in combined radium concentrations between these two areas has been previously noted (Wilson, 2012) and is attributed to differences in geochemical conditions within the aquifer system that favor the adsorption of radium on aquifer materials where the aquifer is not buried by younger rocks and the release of radium into solution where the aquifer is buried by younger rocks.

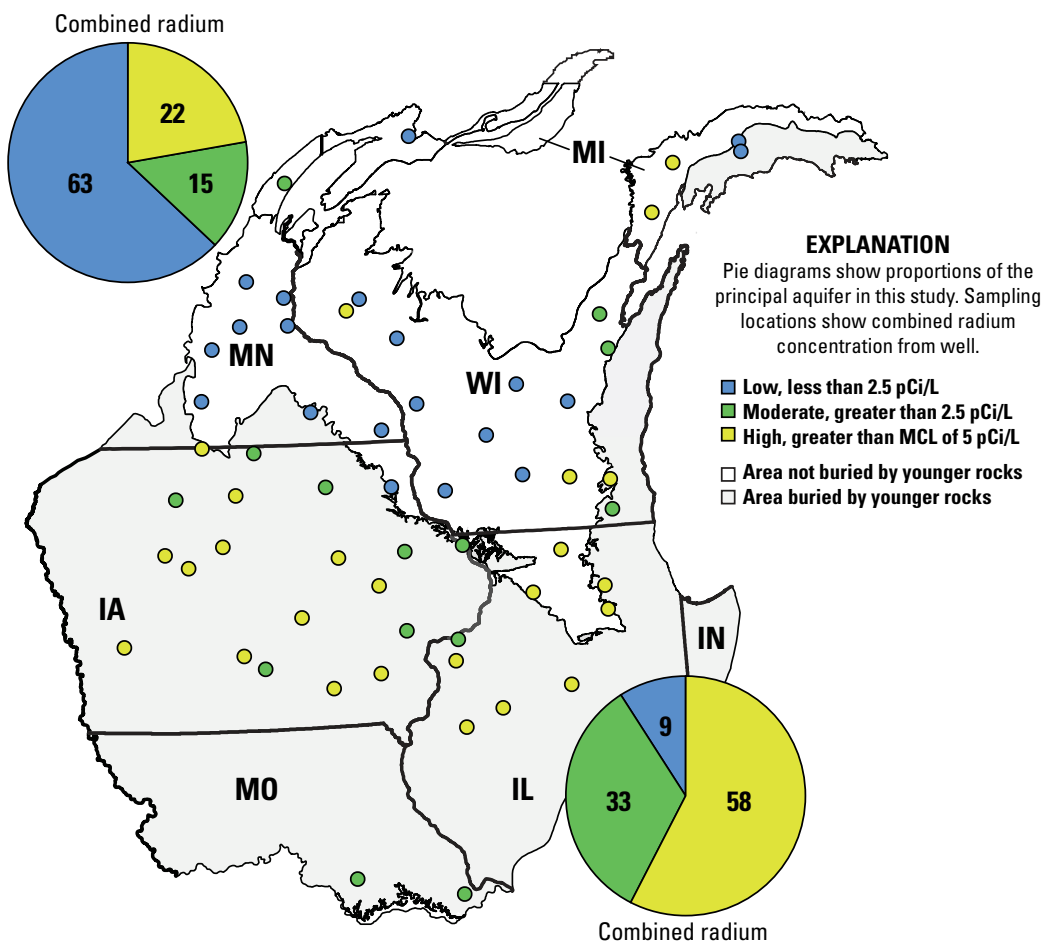

By Paul Stackelberg

SELECTED REFERENCES

Arnold, T.L., Bexfield, L.M., Musgrove, MaryLynn, Lindsey, B.D., Stackelberg, P.E., Barlow, J.R., DeSimone, L.A., Kulongoski, J.T., Kingsbury, J.A., Ayotte, J.D., Fleming, B.J., and Belitz, Kenneth, 2017a, Groundwater-quality data from the National Water-Quality Assessment Project, January through December 2014 and select quality-control data from May 2012 through December 2014: U.S. Geological Survey Data Series 1063, 83 p., https://doi.org/10.3133/ds1063.

Arnold, T.L., Bexfield, L.M., Musgrove, MaryLynn, Lindsey, B.D., Stackelberg, P.E., Barlow, J.R., DeSimone, L.A., Kulongoski, J.T., Kingsbury, J.A., Ayotte, J.D., Fleming, B.J., and Belitz, Kenneth, 2017b, Datasets from groundwater-quality data from the National Water-Quality Assessment Project, January through December 2014 and select quality-control data from May 2012 through December 2014: U.S. Geological Survey data release, https://doi.org/10.5066/F7W0942N.

Belitz, K., Jurgens, B., Landon, M.K., Fram, M.S., and Johnson T., 2010, Estimation of aquifer scale proportion using equal area grids-Assessment of regional scale groundwater quality: Water Resources Research., v. 46, 14 p., doi:10.1029/2010WR009321.

Burow, K.R., and Belitz, Kenneth, 2014, Groundwater studies-Principal aquifer surveys: U.S. Geological Survey Fact Sheet 2014-3024, 2 p., http://dx.doi.org/10.3133/fs20143024.

DeSimone, L.A., McMahon, P.B., and Rosen, M.R., 2014, The quality of our Nation's waters - Water quality in principal aquifers of the United States, 1991-2010: U.S. Geological Survey Circular 1360, 151 p., https://dx.doi.org/10.3133/cir1360.

Siegel, D.I., and Mandle, R.J., 1984, Isotopic evidence for glacial meltwater recharge to the Cambrian-Ordovician aquifer, north-central United States: Quaternary Research, v. 22, no. 3, p. 328-335.

Toccalino, P.L., Norman, J.E., Phillips, R.H., Kauffman, L.J., Stackelberg, P.E., Nowell, L.H., Krietzman, S.J., and Post, G.B., 2004, Application of health-based screening levels to ground-water quality data in a state-scale pilot effort: U.S. Geological Survey Scientific Investigations Report 2004-5174, 64 p

Toccalino, P.L., Norman, J.E., and Schoephoester, K.M., 2014, Health-based screening levels for evaluating water-quality data: U.S. Geological Survey National Water-Quality Assessment Program website, doi:10.5066/F71C1TWP, accessed at https://water.usgs.gov/nawqa/HBSL.

Wilson, J.T., 2012, Water-quality assessment of the Cambrian-Ordovician aquifer system in the northern Midwest, United States: U.S. Geological Survey Scientific Investigations Report 2011-5229, 157 p.

Young, H.L., 1992, Summary of ground-water hydrology of the Cambrian-Ordovician aquifer system in the northern Midwest, United States: U.S. Geological Survey Professional Paper 1405-A, 55 p.

\section{Principal Aquifer Studies}

The USGS NAWQA Project has been assessing the quality of groundwater since 1991. The NAWQA studies include Land Use Studies (LUS), Major Aquifer Studies (MAS), and Principal Aquifer Studies (PAS). These three study types are based on sampling networks of wells distributed across an area of interest. The LUS networks typically consist of observation wells that are relatively shallow, MAS networks typically consist of domestic-supply wells that are intermediate in depth, and PAS networks typically consist of public-supply wells that are relatively deep. A national synthesis of shallow and intermediate depth groundwater quality was reported by DeSimone and others (2014), and a regional synthesis of shallow and intermediate depth groundwater quality from the C-O aquifer system was reported by Wilson (2012). This fact sheet provides a summary of PAS data for 60 public-supply wells sampled in 2014 in the C-O aquifer system (data available in Arnold and others, 2017b).

The PAS assessments like this one allow for the comparison of constituent concentrations in untreated groundwater with benchmarks established for the protection of human health and for aesthetic qualities of drinking water and also provide a basis for comparison of groundwater quality among the principal aquifers. The data collected by the NAWQA Project include chemical analyses generally not available as part of regulatory compliance monitoring, including measurements at concentrations much lower than the levels used as human-health benchmarks and measurements of constituents that can be used to trace the sources and movement of groundwater.

\section{For more information}

Technical reports and hydrologic data collected for the USGS NAWQA Project may be obtained from:

\section{NAWQA Chief Scientist}

U.S. Geological Survey

12201 Sunrise Valley Drive, MS 413

Reston, VA 20192-0002

Email: nawqapublicinfo@usgs.gov

WEB: https://water.usgs.gov/nawqa/ 